\title{
Theoretical Models of Teaching Creativity - Critical Review
}

\author{
Krzysztof J. Szmidt \\ University of Lodz, Poland \\ E-mail address: krzysztof.szmidt@uni.lodz.pl
}

\author{
Anna Majewska-Owczarek \\ University of Lodz, Poland \\ E-mail address: anna.majewskaowczarek@uni.lodz.pl
}

\section{ARTICLE INFO}

\section{Keywords:}

Didactics of creativity

Heuristic model of teaching

Teaching creativity

Teaching strategies of creativity

Teaching method of creativity

\section{Article history:}

Received 15 May 2020

Received in revised form 10 July 2020

Accepted 11 July 2020

ISSN: 2354-0036

DOI: 10.2478/ctra-2020-0004

\section{A B S T R A C T}

This paper is an attempt to present selected classifications of models of teaching creativity, which may have been found in literature over the last years. Models of teaching creativity are understood by the authors as well-developed systems of statements, based on a specific theory of creativity and concerning strategies and methods of teaching creative thinking and action, conditions of education, the role of a teacher in that process, and evaluation of education results. The paper describes several classifications of such models, including the authors' own proposal, and presents a more detailed description of the heuristic model of teaching creativity. In the conclusion, the authors propose a thesis that the issue of methods of teaching creativity is open and the answer to the question about the best teaching methods in that obligation, which is interesting from the pedagogical point of view, should, as in the whole didactics, be answered by teachers, using their knowledge about creativity and its development.

\section{INTRODUCTION}

When educators and psychologists of creativity found out that teaching creative thinking is possible, as in the case of other complex cognitive skills, didactic concepts started to appear. Their authors proposed how to do that in an optimal manner, in various school and off-school environments, and on various levels of teaching. We will understand the "theoretic models of teaching creativity" as systems of statements based on a specific theory of creativity, justified and verified using empirical research, and concerning goals, contents, methods, and means of teaching creative thinking, activities of students at all ages, and the role of a teacher (educator) in that process. Those models (should) include 
answers to the following questions of didactics of creativity (Szmidt, 2007; 2013a; 2018a; 2018b):

(1) In what way - using what educational (therapeutic, training etc.) methods - should potential creative skills of students at all ages be stimulated? How to develop creative skills that have already been awakened, how to raise them to a higher level or subject them to cultural sublimation?

(2) How to help students transfer skills they have learnt to everyday life and professional practice?

(3) Which teaching methods and tasks are most effective in that process?

That group of questions may include more detailed issues, such as:

(4) In what psychological and didactic conditions should the process of teaching creativity take place?

(5) Which didactic principles should be used by teachers of creativity and, wider yet, what does the essence of their pedagogical role consist in?

(6) What properties and skills should a good teacher of creativity have?

(7) Which properties of a school climate (atmosphere) or, in better words, school (or cultural centre, education centre, etc.) culture favour stimulation and development of creative skills and which properties harm them (issue of stimuli and inhibitors of creativity)?

(8) What is the importance of competition, rivalry, and contests in teaching creativity?

(9) Does teaching creativity require the use of the means of teaching specific for didactics of creativity (equipment, tools etc.)? If it does, which tools are most effective and how to construct and use them?

Obviously, these are not all important questions of the didactics of creativity; however, those listed above seem to us to be the most important for the discussed issue of models of teaching creative skills.

All of those issues are described by Kettler, Lamb, and Mullet (2018, p. 72) as "Integrated Creative Pedagogy" and perceived as part of Systematic Development of Creativity in Schools. The authors write, "Systematic development of creativity consists in combining resources and focusing permanently on three areas: (1) curriculum and resources, (2) professional education and training, and (3) environment of support and creative responsibility" (p. 231). All those areas are complex and multilayer; employees of each educational centre who want to follow a certain established model of teaching creativity should become aware that it requires a long-lasting and continuous pedagogical involvement. We will return several more times to the conclusions from research and the principles of didactics of creativity by the authors of that excellent textbook of creative pedagogy. 
The purpose of this paper is to describe, in a short and synthetic manner, the most important, in the authors' opinion, classifications of theoretic models of teaching creativity, which may have been found in pedagogic literature over the last fifty years, and to evaluate them initially (both those accusations are directed, for example, at de Bono - see Sternberg \& Lubart, 1999). Authors of the concepts described below deduce their didactic hypotheses from more general statements on the nature of creativity and its development; they design specific educational influences by referring to principles of the creative process and, although not all of them to the same extent, they evaluate the results of proposed teaching methods using diagnostics and verifying research. In other words, they propose a certain theory of teaching creativity and then subject it to Popper's falsification. An approach to teaching creativity selected and called by us "a heuristic model" will be characterised in more detail further in this paper.

Description of theoretic models of teaching creativity should, in our opinion, include the following items: (1) theoretic assumptions of the model - what creativity is; how the creative process and development of creativity is understood; what cognitive, motivating, and operational skills (abilities, properties) are the most important for the creative success; (2) strategies, methods, and techniques of teaching creativity - what manners of teaching creative competences are most effective in specific conditions and on a specific level of education; what organizational forms of teaching creativity best follow the assumptions of the model; are there any teaching means recommended in that process and, if there are, which means are recommended; (3) role of a teacher of creativity - who a teacher of creativity is or should be; what psychological competences they should have and what education and teaching style they should use (i.e., which principles they should follow); (4) evaluation of teaching results - what the best ways are to assess and verify results of teaching creative skills; which techniques of didactic diagnosis and measurement should be used and what their limitations are.

Not all models of teaching creativity described here answer those questions completely and in the same manner; however, we believe that concepts of that type, which are welldeveloped and which aspire to the name of scientific concepts (didactic paradigms, as called by Klus-Stańska (2018), should elaborate on those issues in a scientific manner.

\section{SELECTED CLASSIFICATIONS OF MODELS OF TEACHING CREATIVITY}

Models of teaching creativity are classified in various manners, though not often by scientists representing creative pedagogy and psychology, who seem to be more interested in typologies of techniques and tricks used in creative processes (e.g., VanGundy, 2005; Treffinger, Schoonover \& Selby, 2013; Sternberg, 2017; Starko, 2018; Beghetto, 2019). 
As proposed many years ago by the one of the authors (Szmidt, 2003, p. 122), two general models of teaching creativity may be distinguished: (1) lesson units organized particularly for this purpose that are more psycho-educational classes than lessons in a specific subject and that make a school or educational centre offer more attractive (e.g., creativity lessons, creative workshops, creative thinking training, creative drama etc.); (2) including contents related to creativity and creative skills in curricula of existing subjects (e.g., Polish, DIY, physics), filling them with issues of creativity related to a specific discipline (e.g., including heuristic methods, such as a brainstorming, value analysis, or SCAMPER in traditional school subjects).

In the first case, we are dealing with a specialist separate teaching of creativity (creativity taught as a new "subject"), whereas in the latter one, with general, non-specific teaching (creativity as a subject content and a teaching method).

Treffinger, Schoonover \& Selby (2013) distinguish three levels of teaching and learning creative thinking considered equivalent to productive thinking: (1) Foundations, (2) Real Life Opportunities and Challenges, and (3) Realistic Tasks. Creative Problem Solving methods are best for teaching creativity in their concept, which, depending on the education level, may be divided into methods teaching and generation of solution ideas (e.g., brainstorming, attribute listing, Force-Fitting, SCAMPER, or Morphological Matrix) and methods teaching evaluation and selection of the best solutions (Focusing Tools, e.g. Hits and Hot Spots, Evaluating Matrix, Sequencing etc.). In their opinion, the Torrance Incubation Model (TIM) is a model of teaching creativity that integrates various methods of developing creative skills. As they write (Treffinger, Schoonover, \& Selby, 2013, p. 204), "The TIM was intended to be a dynamic and flexible tool for organizing and delivering creativity skills and providing for practice, incubation, and application of those skills in any content area - not to define or prescribe a specific set of creativity skills or tools." Among other teaching strategies important for teaching creative skills, they also mention the system of CoRT exercises by de Bono (1973), Six Sigma developed by Motorola, Synectics, and Creative Problem Solving.

Beghetto (2017, p. 549) believes that creative teaching, such as other forms of teaching, is a complex and multi-form activity. The author distinguishes three forms of creative teaching: (1) teaching about creativity; (2) teaching for creativity, and (3) teaching with creativity. Those three types of teaching creativity listed above are distinguished by their author depending on different pedagogical purposes and a specific knowledge necessary for each of them. We will briefly describe them as understood by that author. 


\section{Teaching about creativity}

In Beghetto's (2017) opinion, the purpose of teaching about creativity is to provide students with knowledge on creative phenomena and to help them to understand such phenomena. This type of teaching includes, therefore, a presentation of the definition of creativity, manners of understanding and expressing it, and how a process of creativity development looks like, as well as pointing to individual and contextual factors facilitating or inhibiting that development. In this case, actions taken concern both teaching creativity in relation to the specificity of the discipline concerned (e.g., through answers to questions, such as "What role in mathematic thinking and reasoning is played by creative imagination?), and running independent courses of creativity. Knowledge needed for this type of teaching, which should be mastered by a teacher, includes key concepts of creativity, theories and research related to that topic, as well as pedagogic expertise in how to teach groups of people who differ as to age or for instance the discipline they represent.

\section{Teaching for creativity}

Teaching for creativity consists, in the author's opinion, in developing skills of creative problem solving, strengthening creative attitudes, teaching principles of creative thinking, and forming the ability to transfer skills for creative problem solving to the sphere of real challenges in personal and professional life. Activities performed during teaching creativity help to reach its main goal, which is to increase the level of students' creativity. As in the case of teaching about creativity, students' creativity may be developed in the context of specific thematic areas or with direct reference to creativity development programs.

Teaching for creativity with reference to programs dedicated directly to development of creativity consists in using exercises for developing general creative skills. To illustrate teaching for creativity in the context of a specific discipline, to show how to develop principal creative skills, Beghetto refers to an example of teaching for creativity in the context of teaching elements of narration. In the example activity described by the author, a teacher lists elements obligatory for students, such as main characters, conflict, or viewpoint. Then, the teacher asks for several examples illustrating each of the required elements and goes on to provide students with a possibility of expressing their creative narration based on their own ideas. The example shows that there are two ways in teaching that are well described with the sentence by one of the authors of this paper "We may teach about sonnets or write our own sonnet" (Szmidt, 2018).

Therefore, in teaching for creativity, a knowledge is necessary about how to strengthen creative attitudes or about what may inhibit their development as well as pedagogical knowledge on recipients, their possibilities and limitations, possible obstacles, and how creativity may be used in specific social or cultural contexts. 


\section{Teaching with creativity}

The third type of creative teaching distinguished by Beghetto (2017) refers to a creative approach to teaching. Creativity is present here in the act of teaching rather than in its subject or result. Creative teaching may, therefore, create a context facilitating the support of students' creativity. This type of activity helps to create conditions of learning in a group, where students are encouraged to show similar behaviour. It also facilitates modelling behaviours characteristic of people with a creative attitude, such as readiness to take risks, learning from one's mistakes, or searching for and examining various ideas.

The skill of creative teaching requires, therefore, knowledge about creativity, referring it to subjects taught, and using different activities depending on the type of a group, such as for instance students at various ages. However, it does not consist only in using readymade strategies and techniques, but in combining them with an on-going observation of the group and a flexible approach to the course of the lesson. Beghetto (2017) calls it a "disciplined improvization."

Let us look once again at the example of teaching creativity in the context of teaching narration elements. This example referred to teaching creativity in reference to a specific discipline. An opportunity to create was possible for students owing to a creative idea of the teacher. Therefore, it is an example that shows teaching creativity concurrently with creative teaching. It leads us to a thesis that teaching creativity is closely correlated with creative teaching. Is it not a fact that when we start teaching about creativity in a creative manner, we start to actually teach creativity? And when we exclude creative teaching from the process of teaching creativity, it becomes a non-creative teaching about creativity or simply teaching a specific discipline? More similar questions may be asked as, being a bit artificial, separation of the process of teaching about creativity from the process of teaching creativity itself raises a lot of doubt as to practice and not only theory.

The authors of the present paper believe that it is not worth to be afraid of a noncreative way of teaching creativity. We will use an example referring to an experience of one of the authors of this paper, related to coaching a team in the Odyssey of the Mind educational program. The goal of the program is to develop the skill of creative problem solving. As a coach of a team that participated in it, the author performed creativity training with the use of materials provided by the organizers and not knowing that it was a creativity training. Only at the end of the task did this author become aware of what was actually being done with the team, after beginning to read literature explaining what such training consists of. At that moment, the author saw how knowledge about creativity may help develop when coaching the team and also noticed the value of learning issues relat- 
ed to creativity, starting from action and experience. Experiencing teaching creativity in a creative manner helped the author understand the theory. However, it was not learned in a creative manner, but simply studied it in a traditional way.

Therefore, separation of teaching about creativity is justified in the context of focusing on the theoretical and scientific aspect of creativity. Creativity will, however, be taught in a rather non-creative way. So in the context of creative teaching, the division by Beghetto, although valuable from the theoretical viewpoint, boils down to the division into teaching creativity and creative teaching anyway.

Kettler, Lamb and Mullet (2018, p. 95), who we have already mentioned, write as follows when thinking about developed concepts of teaching creative behaviours:

Models of teaching are also treated as training projects which create a particular environment influencing interactions and behaviours of students towards the desired learning result. Specific models of teaching include guidelines for developing challenges and actions owing to which students' work may achieve specific goals. Models are useful as they may become an element uniting a curriculum with instructions.

Over time, as they maintain, several models of teaching creativity were formed, understood as the main goal of a didactic influence (a separate manner of teaching creativity, as we understand it) and as supplementing contents and methods of teaching other subjects with those related to creativity (non-specific and additional teaching creativity). The use of such models by teachers brings many benefits. For instance, it provides guidelines for developing a curriculum, exercise techniques, instructions how to use them and teaching resources, and ensures continuous training and one's improvement with the use of the model. The authors recognize the following as such models of teaching creativity (Kettler, Lamb, \& Mullet, 2018, p. 96):

- Torrance Incubation Model;

- Creative Problem Solving;

- Project-Based Learning;

- Problem-Based Learning;

- Design-Based Learning;

- Creative Productive Independent Investigations.

\section{MODELS OF TEACHING CREATIVITY - THE AUTHORS' OWN PROPOSAL}

Among the theoretically justified concepts of teaching creativity in a direct manner, frequently described as the main purpose of didactic influence (teaching creativity rather than teaching about creativity or creative teaching), we have distinguished the following types, developed scientifically and didactically: (1) Divergent Model; (2) Torrance Incuba- 
tion Model; (3) Creative Problem Solving; (4) Heuristic Model; (5) Explorations - Combinations - Transformations.

It may be surprising that we have refrained from including Project-Based Learning or Design Project Method in this classification. We have done that on purpose as we believe that rather than developing students' creativity both those theoretic models are directed at developing many practical skills, only some of which are directly related to stimulating creative skills, though development of creative skills is mentioned in the model's goals. Pro-creative goals are achieved here somewhat "accidentally" and creative operations are treated as means to achieve other goals. The classification does not include creative drama either, as its educational purposes exceed supporting creative skills and focus on social goals and functioning in a group (family, peers, etc.). Let us emphasize it once again: here, we are interested only in those models of teaching creativity that are directly related to stimulating, supporting, and developing specific skills of students' creative attitudes; ones connected to their creative thinking and acting.

We will describe one of the models listed above, focusing on its theoretical assumptions rather than practical applications. Out of necessity, the description will be short as full characteristics and assessment of those concepts would require a vast volume of discussion.

\section{HEURISTIC MODEL}

\section{Theoretic assumptions}

Sometimes, you may feel that only creativity may help us. This a bit humorous but also slightly ironic statement is a conscious effort of the authors. Websites, books, and advertising watchwords encourage us and show us the need to develop creativity: "How to be creative? 10 rules of creative people," "Be creative and imaginative," "Free your creativity." Mugs, bags, lanyards, and keychains with almost omnipresent "be creative" catch our eye nearly every day. People take part in trainings of creativity held by specialists and exercise their verbal, associative, and expressive fluidity. All this is good. However, in that mass of watchwords and activities, we start to miss, in the opinion of one of the authors of this paper, one of the fundamental components necessary to develop human creativity. We will discuss this issue below.

Like many other authors, when writing about creativity, Sawyer (2019, p. 567) means a specific process that leads to generation of results that are new and useful for a specific social group, whose experts are recognized as professionals in that discipline. Therefore, a question arises about methods, tools, and means that may be used to develop such products. Heuristics is a discipline that took up the challenge of seeking the answer to this question; it is described as "a skill of discovering new facts and relationships between 
facts, leading to learning new truths" (Szymczak, ed., 1998, p.739). As a science that focuses on making discoveries, heuristics leads an individual to considering what laws govern creative thinking; it aspires to "discover rules regulating creativity and presenting them in the form of creativity patterns, i.e. systems of conduct facilitating the realization of creative efforts" (Góralski, 1998, p. 36). As a methodology of creative action, it specifies rules, principles, and guidelines of creative problem solving.

When writing in their work about creative problem solving based on, among other things, heuristic techniques, Bieniok, Gruszczyńska-Malec, and Królik (2013) distinguish five stages of proceeding. The first of them is goal ( $\mathrm{C}$ - Cel [Goal]). At this stage, a problem is formulated and we agree on what we are aspiring to. Then, it is time for collecting specific information needed to solve the problem, making observations, and referring to one's own experiences or opinions of other people (I - Informacje [Information]). After that, the next stage consists in seeking a wide range of ideas to solve the problem using techniques of creative thinking ( $P$ - Pomysły [Ideas]), in order to proceed to evaluation whose goal is to select the one that is the most original and that achieves the goal best (O - Ocena [Evaluation]). The last stage is implementation of the idea and determination of steps allowing the solution to be used in practice (W - Wdrażanie [Implementation]).

The whole procedure is open, both at separate stages and in its entirety. It enables one to generate the largest number of ideas, increasing probability of original ideas actually forming. Collecting information is very wide; the collected knowledge pertains to many disciplines and an attempt is made to look at the problem at hand in a multi-aspect manner. The stage of implementation does not assume that the process is completed at all.

That multi-aspect viewpoint used in the heuristic model, use of specific techniques helpful in generating creative ideas, and openness in searching for solutions on individual stages is not, however, the end of that richness. What is really valuable here is the iterative nature of the heuristic model. It is not based on a simple passage from stage to stage or completion of each of them like with a checklist, but it assumes that it is possible to return to specific stages and take new data in the process into account even if such data appears after the stage concerned has been completed and after specific arrangements have been made. Therefore, proceeding in the heuristic model paves the way to generating newer and newer ideas, which do not resemble patterns we have (Nęcka, 2005).

An important value of heuristics is also the fact that it pays attention to the "forgotten" component essential in developing creative thinking, one that has already been mentioned before. Mumford and Norris (1999) write about it, closely combining heuristics with expert knowledge. They believe that declarative knowledge of a discipline concerned is necessary for creative problem solving. Regarding creativity, a lot is written about a crea- 
tive attitude and creating conditions for stimulating creativity. Inhibitors and stimuli of its development are described in quite a detail. And although the word "knowledge" is mentioned in the context of creativity, it does not seem entirely obvious that it is good not only to verify that knowledge regularly when it is needed; not only to keep it in a short-term memory or until it is verified but also to expand it, to read, to memorize.

Knowledge enables us to understand the world better, to have a wider outlook, from many perspectives, as is proposed by heuristics. It is a good tool to provide us with a wide area of search already in the beginning of problem solving. It is an excuse to study more and more detailed issues from many fields, which may be an inspiration to create original solutions. It is not, obviously, a guarantee that they will be there but the bigger the source is, the more you can take from it.

The heuristic model itself favors development of knowledge which appears in various forms here. It is general knowledge we have, the one we obtain at the stage of solving a problem. It is expressed in rules, principles, and guides for searching for the solution; manners of preparing, realizing, and evaluating creative achievements (Góralski, 1998). Therefore, here we deal not only with factual knowledge, but also with procedural one, which uses facts to formulate specific strategies of problem solving.

The heuristic model is also useful for developing fluency, flexibility, and originality of thinking. It allows us to observe relationships between disciplines, which are far from each other; it gives us an ability to look at a problem at hand from many points of view. It exercises obstinacy and perseverance in searching for a solution.

As there is no need to end the problem-solving process at the implementation stage, the increase in knowledge and creative skills taking place in the heuristic procedure is spiral. Therefore, a perspective of continuous development opens and each situation may be used for this purpose. Obstacles that may block that development may be treated as opportunities to make a step forward; any steps backwards will not be backward if no resignation from creative problem - solving takes place. What is important is the awareness of the phase of frustration and incubation in the stage of creating ideas (Bieniok, Gruszczyńska-Malec, \& Królik, 2013). However, using the knowledge and experience that have already been obtained will increase the probability of finding the most creative solution; a solution that may become an inspiration for seeking further.

Perhaps it is the lack of decision about implementing the idea concerned that may be a trap of creative problem solving based on the heuristic model. There is risk that when a solution appears it will still not be implemented due to a constant inflow of new data, as well as the desire to improve and constantly search for that "best" solution. Therefore, 
one should remember that the heuristic model assumes that the solution may be incorrect and may not work. At the same time, a situation may take place where a solution is not found. The heuristic model, therefore, does not guarantee that a creative solution will be found; however, is such a guarantee possible at all?

The use of the heuristic model may be a great way to enrich teaching creativity during teaching various subjects. In the reality of a modern school, in teaching where an issue at hand is looked at from the perspective of a specific subject (despite everything, integration of subjects still seems to be wishful thinking), the multi-aspect and heuristic approach will be possible to apply, but by a teacher who would show such a manner of thinking to students. Teachers themselves will need, therefore, vast knowledge, high fluency, flexibility, and originality of thinking, openness to new things, and "disciplined improvisation" described by Beghetto (2017, already been mentioned above). Working based on heuristic models that enable students to increase their knowledge will teach them the art of problem finding, discussing, formulating hypotheses and persevering in their search (Szmidt, 2017). It will help them to satisfy their need for development and to develop competences needed for functioning in the quickly changing reality. Therefore, it is worth to start working seriously using methods that are opposites to simple delivery of knowledge and test-mania. When children learn about something new, for instance a machine, they observe it, look at how it works, and examine its possibilities. It is only after such an observation that they use the process of construction when they create their own machines. Then, they learn various laws governing the world. The children do not start from following instructions. Let that be an inspiration for us.

\section{Teaching strategies, methods, and techniques}

It has been assumed, in particular in the Polish psychology of creativity (Dobrołowicz, 1993), that heuristic procedures (guidelines) are called rules, methods, or techniques. They are at different levels of generality and they perform different functions in the problem-solving process (Dobrołowicz, 1993). Heuristic rules are the most general guidelines that are supposed to facilitate the course of the creative process (e.g., the rule of stages of the problem-solving process, the rule of postponed evaluation, the rule of using what you already know, the rule of combining far associations, the rule of using intuitive thinking, the rule of using paradoxes, the rule of a perfect solution, etc.).

Details of general heuristic rules are provided in methods and techniques of problem solving. Methods consist of all mental and practical actions that have been selected as appropriate and performed in a specific order. Each method uses specific techniques understood as operations facilitating completion of stage goals in solving complex problems. Ex- 
amples of methods include associative methods, methods using analogies or metaphors, methods of transforming objects or their representations, visualization methods, or wishful thinking methods. Techniques used as part of those methods include, for example, crushing representations, superpositions, identification with an object, problem redefining, modification of a solution, techniques from CoRT by de Bono (1973), such as random word, ideatons, mindmapping, accident, Six Thinking Hats, Plus - Minus - Interesting, etc.

As Dobrołowicz (1993) maintains, it is expected that each method based on a certain fundamental idea (rule) becomes a manner of realizing the whole creative process, i.e. namely from the stage of discovering and formulating a problem (problem finding stage), through the stage of generating solutions (problem solving), up to their evaluation and verification (problem evaluating). However, not all heuristic methods cover all those stages to the same extent; most of them focus on searching for creative solutions (problem solving stage).

In general, heuristic methods are divided into: 1) analytical methods and 2) intuitive methods (Góralski, 1989; Antoszkiewicz, 1990). Analytical methods consist in solving a complex problem consciously and gradually by making specific steps defined by the procedure and dividing the problem into its components, which are often analysed and solved separately. They include complex heuristic methods, such as morphological analysis, functional analysis, ARiZ Altszuler system, or Sawyer's (2013) procedure called "Zig Zag." Intuitive methods refer to other creative thinking mechanisms consisting in intuition, connecting far associations, wishful thinking, and fantasizing (What would happen if...), using accidents and illumination (insight), and speculating and hypothesizing, which are often based on unclear conditions. That group of methods includes brainstorming, synectics, lateral method, and perfect patterns method. There are also eclectic methods, which are based on various sources, and which attempt to use the advantages of both analytic and intuitive methods. Those include SCAMPER or CPS. Depending on the level of complexity, heuristic methods may also be divided into complex (e.g., synectics, SCAMPER, morphological analysis) and simple ones (classic brainstorming, bisociation technique, Random Word).

Didactics of creativity includes many widely used and well-known heuristic methods that are already well-established in teaching on various levels of the education system, such as brainstorming and its variations, functional analysis, morphological analysis, synectics, or lateral methods. Each year, newer and newer methods are created and then propagated by scientific institutes, authors of books and websites, and centers educating management staff in creative problem solving. Heuristics itself becomes a subject of creativity (ref. to "TRoP" by Nęcka, 1994; Fast Creativity and Innovation by Bytheway, 2007; 
Zig Zag by Sawyer, 2013; "Eksploracje - Kombinacje - Transformacje” by Szmidt, 2013b; Method of creative discussions by Okraj, 2012; 2013; 2015).

\section{The role of a creativity teacher}

In the heuristic model, a creativity teacher becomes similar to a creativity coach who, in their didactic work, uses a number of principles for coaching development or meeting groups or, as Góralski $(1998,2003)$ wants, to a master-follower of creativity patterns. The first vision sees a teacher - a creativity coach - as a professional educator or psychologist who, apart from substantive knowledge in creativity (teaching about creativity) and its selected disciplines, has well-developed psycho-pedagogical competences useful in coaching development and education groups. The most important of them include skills of using principles of facilitating a group process, ludicity, developing autonomous cognitive motivation, strengthening the creative process (orientation to the process rather than to the product), fighting obstacles, personal creativity and creative teaching, and, the one that is important nowadays, as we deal with excess of creative production, namely the principle of fighting rubbish (Szmidt, 2013a). Many other pedagogical principles used in teaching heuristics are listed by Amabile (1992), Sternberg (2010, 2019), Cropley (1992, 2001), Kettler, Lamb and Mullet (2018), Starko (2018) and many other authors (ref. to the overview: Szmidt, 2013a).

The role of a creativity teacher as a heuristics master assumes that, as Góralski writes (2003, pp. 95-98): (1) the teacher outclasses others with creative skills and proficiency; (2) the teacher is an exceptionally highly-qualified craftsperson ("they love what they do," p. 95); (3) the teacher is a personal model ("it is necessary that they form their own school of mastery," p. 97); (4) the teacher believes in themselves and in their group of reference, communication skills, intuition, perceptiveness and flexible, open mind, distance to generally accepted judgements, inquisitiveness, vigilance, and many other virtues of mind and spirit ("faithful to ideals and the truth," p. 98); (5) the teacher has outstanding creative achievements.

As a consequence, the author defines a teacher-master as follows: "A master is a person who bears testimony to the attainability of the vision and the change of the world, who acts creatively, in accord with the given measure of necessity and possibility, who has obtained an outstanding efficiency of achievements, who is a model of fulfilled humanity and who is someone's teacher" (Góralski, 2003, p. 98). Here, it seems justified to use a great dose of pedagogical scepticism that originates from a lot of our own school and off-school experience related to teaching creative behavior: how many creativity teachers do we know that meet those criteria? And more critically: how many creativity teachers are able to meet those criteria? 


\section{Evaluation of teaching results}

In descriptions of the heuristic model of teaching creativity, it is difficult to find clearly formulated strategies or methods of examining didactic efficiency of that model. As main methods of teaching creativity here include methods and techniques of creative problem solving, the manners of diagnosing their efficiency should and often do include psychometric (quantitative) methods used in the Guilford tradition to measure fundamental factors of divergent thinking (fluency, flexibility, originality of thinking, elaboration and sometimes sensitivity to problems). A lot of light is shed on the manner of using techniques of that type, also in the school environment, and on their limitations by the cycle of works edited by Runco (1997, 2012a, 2012b, 2013; also ref. to Runco \& Acar, 2019). The issue of how to measure the efficiency of heuristic methods and, more generally, the efficiency of methods for developing creative skills is a serious dilemma; one that we cannot discuss here due to the lack of space. Recently, a lot of attention has been given to it (ref. to the review of attitudes by Kaufman, Plucker, \& Baer, 2008; Cropley \& Cropley, 2015; Quian, Plucker, 2017; Said-Metwaly, Kyndt, \& Van den Noortgate, 2017; Beghetto, 2017; White, 2018). The research clearly shows that teaching creativity through the heuristic methods such as for instance brainstorming, CPS methods, or methods using far associations, facilitates the development of fluency and flexibility of thinking and is a bit less favourable to originality of thinking and sensitivity to problems (Runco, 2013). However, the most important pedagogic question is not which single factors of creative thinking are developed most through those methods, but whether that type of teaching helps students to become creative in future rather than today. The answer to that question requires the use of other methods of examining efficiency of teaching, the departure from a single, mainly quantitative strategy of measurement, and the use of qualitative, biographic-narrative, and, admittedly, introspective techniques. However, this is a topic for another work. To interested readers, we may recommend so far the most complete (in our opinion) proposal concerning the system of diagnosing and measuring the effects of teaching creativity to students on various levels of education, presented by White (2018), a Canadian educator.

Therefore, we should agree with Beghetto (2017, p. 557), who writes:

Developing more sensitive and dynamic methods for measuring teaching for creativity (e.g. simultaneously assessing the confluence of teacher, student, and environmental factors on domain-specific creativity enhancement) is important and much needed area of future inquiry for researchers interested in understanding how teachers might support students' creative thinking and action. 


\section{ENDING - THE QUESTION ABOUT METHODS IS AN OPEN ISSUE}

Teaching creativity is an interesting, but also strange pedagogical profession, the practice of which falls outside easy summaries and general laws of didactics (Szmidt, 2019). The greatest creativity geniuses, such as Beethoven, Gates, or Edison, were taught by teachers they may have nightmares about and, despite that, in their adult life they created works like no other people could. On the other hand, eminent authors mature in schools and academies that have for many decades taught creativity on a constantly high level, such as Juillard School of Music in New York, the German Bauhaus, or Zespół Szkół Plastycznych im. A. Kenara [Art School Complex, named after A. Kenar - an eminent Polish artist] in Zakopane, Poland. When studying the life of much regretted, talented and blind Polish pianist, Kosz, who died in unexplained circumstances at the age of 29, one discovers how great a role in his creative development was played by professor Witeszczakowa, a teacher, whose teaching methods far exceeded the canons of methodological correctness adopted in the 1960s (Karpiński, 2019).

The question about which models of teaching creativity are best for developing creative skills is really an open and difficult one if we remember that Thomas Mann repeated a year at school twice and that for many centuries the highest-class artistic craftsmen were subject, in their youth, to a really strict discipline by their master and senior journeymen. In spite of that, they created remarkably creative things afterwards. In its historic archives, the didactics of creativity has many examples of teachers working with authors outstanding in their later years, who used methods that seem a crime against the freedom of students, their rights, and aspiration to autonomy, and that clearly oppose the canons of correctness adopted by modern pedagogy; methods that are also in conflict with the positive properties of the teaching models presented above. Despite that, let us repeat it again, those students were authors of world-class works (e.g., Komeda or Bałdych, only to list two Polish jazzmen). Once again, it turns out how difficult it is to draw explicit conclusions from a discussion on creativity and its education-related conditions. We are made aware of that once again by thorough studies of well-known and creative academic teachers conducted by Okraj (2019) using the Gruber approach (The Evolving System Approach).

Even the most developed and well-thought-out methods of teaching creativity used by a teacher who does not understand the specificity of that process, which is obviously different than providing information on the morphology of snakeroot, will not bring any benefits to development of students. In this way, we have reached the most important and final principle of teaching each subject: it is the teacher that is the critical link in teaching. That principle applies as well, or maybe most of all, to teaching creative thinking and acting. 
In the end, let us give the floor to Sternberg (2019, p. 101), who has an important thing to say to educators teaching teachers of creativity:

I believe the largest barrier to teaching for creativity is quite simple: Teachers do not know how to do it and have no incentive to learn. They have not learned how to teach for creativity in their training, and standardized test given to students on the basis of which teachers, not just students, will be evaluated place no emphasis on creativity. If we want teachers to teach for creativity, we have to remove the barriers. We could start by teaching teachers how to teach for creativity. Then we could encourage rather than discourage creativity on standardized tests.

\section{REFERENCES}

Amabile, T.M. (1992). Growing Up Creative: Nurturing a Lifetime of Creativity, second edit. Buffalo: C.E.F Press.

Antoszkiewicz, J. (1990). Metody heurystyczne. Twórcze rozwiązywanie problemów. (Heuristic methods. Creative problem solving). Warszawa: PWE.

Beghetto, R.A. (2017). Creativity in Teaching. In J.C. Kaufman, J. Baer, \& V.P. Glăveanu (Eds.). Cambridge Handbook of creativity across different domains (pp. 549-564). New York: Cambridge University Press.

Beghetto, R.A. (2019). Creativity in Classroom. In J.C. Kaufman, R.J. Sternberg (Eds.). The Cambridge Handbook of Creativity. (pp.587-606), second edition. New York: Cambridge University Press.

Bieniok, H., Gruszczyńska-Malec, G., \& Królik, G. (2013). Techniki twórczego myślenia. (Techniques of creative thinking). Katowice: Wyd. Uniwersytetu Ekonomicznego w Katowicach.

Bytheway, C.W. (2007). Fast Creativity and Innovation. Rapidly Improving Processes, Product Development and Solving Complex Problems. Fort Lauderdale: J. Ross Publishing Inc.

Cropley, D.H., \& Cropley, A.J. (2015). The Psychology of Innovation in Organizations, New York: Cambridge University Press.

de Bono, E. (1973). CORT Thinking. Blandford, England: Direct Education Services. Dobrołowicz, W. (1993). Psychika i bariery. (Psyche and barriers). Warszawa: WSiP.

Góralski, A. (1989). Twórcze rozwiązywanie zadań. (Creative problem solving). Warszawa: PWN.

Góralski, A. (1998). Wzorce twórczości. (Patterns of creativity). Warszawa: Wydawnictwo Naukowe SCHOLAR.

Góralski, A. (2003). Teoria twórczości. Eseje filozoficzne i pedagogiczne. (Theory of creativity. Philosophical and pedagogical essays). Warszawa: Wyd. APS. 
Guilford, J.P. (1950). Creativity. American Psychologist, 5, 444-454.

Guilford, J.P. (1968). Intelligence, Creativity and their Educational Implications. San Diego: Robert R. Knapp Publisher.

Guilford, J.P. (1975). Creativity: A Quarter Century of Progress. In I.A. Taylor, J.W. Getzels (Eds.), Perspectives on Creativity (pp. 37-59). Chicago: Aldine Pub. Co.

Guilford, J.P. (1978). Natura inteligencji człowieka. (The nature of human intelligence). Warszawa: PWN.

Karpiński, K. (2019). Tylko smutek jest piękny. Opowieść o Mieczysławie Koszu. (Only sadness is beautiful. The story of Mieczysław Kosz). Kraków: Wydawnictwo Literackie. Kaufman, J.C., Baer, J., \& Plucker, J.A. (2008). Essentials of Creativity Assessment (Essentials of Psychological Assessment). New York: Wiley.

Kettler, T., Lamb, K.N., \& Mullet, D.R. (2018). Developing Creativity in the Classroom. Learning and Innovation for $21^{\text {st }}$-Century Schools. Waco: Prufrock Press Inc.

Klus-Stańska, D. (2018). Paradygmaty dydaktyki. Myśleć teorią w praktyce. (Didactics paradigms. Think theoretically in practice). Warszawa: PWN.

Nęcka, E. (1994). TRoP ... Twórcze Rozwiązywanie Problemów. (CPS...Creative Problem Solving). Kraków: Oficyna Wydawnicza „Impuls”.

Nęcka, E. (2005). Psychologia twórczości. (Psychology of creativity). Gdańsk: GWP. Okraj, Z. (2012). Funcje dyskusji w stymulowaniu twórczego myślenia studentów. (Discussion functions in stimulating student's creative thinking). Kielce: Wyd. UJK. Okraj, Z. (2013). Alfabet twórczych dyskusji. (Alphabet of creative discussions). Kielce: Oficyna Wydawnicza „Ston2”.

Okraj, Z. (2015). Twórcze rozwiązywanie problemów z zastosowaniem nowych technik dyskusji. Teoria - badania - trening. (Creative problem solving using new discussion techniques. Theory - research - training). Kielce: Wyd. UJK.

Okraj, Z. (2019). Bez szablonu. Twórcza praca w doświadczeniach nauczycieli akademickich. (No template. Creative work in the experience of academic teachers). Warszawa: Difin.

Quian, M., Plucker, J.A. (2017). Creativity Assessment. In J.A. Plucker (ed.), Creativity \& Innovation. Theory, Research and Practice (pp.223-235). Waco: Prufrock Press.

Plucker, J.A., Makel, M.C., \& Quian, M. (2019). Assessment of Creativity. In J.C. Kaufman, R.J. Sternberg (eds.) The Cambridge Handbook of Creativity (44-69), second edition. New York: Cambridge University Press.

Runco M.A., (ed.) (1997). The Creativity Research Handbook, vol. 1. Cresskill: Hampton Press.

Runco, M.A., (ed.) (2012a). The Creativity Research Handbook, vol. 2. New York: Hampton Press inc. 
Runco, M.A., (ed.) (2012b). The Creativity Research Handbook, vol. 3. New York: Hampton Press inc.

Runco, M.A., (ed.) (2013). Divergent Thinking and Creative Potential. New York: Hampton Press Inc.

Runco M.A., \& Acar S. (2019). Divergent Thinking, In: J.C. Kaufman \& R.J. Sternberg, eds. The Cambridge Handbook of Creativity (224-255), second edition, Cambridge University Press, New York.

Said-Metwaly, S., Kyndt, E., \& Van den Noortgate, W. (2017). Approaches to Measuring Creativity: A Systematic Literature Review. Creativity: Theories - Research - Application 4( 2), (238-275).

Sawyer, K. (2013). Zig Zag. The Surprising Path to Greater Creativity. San Francisco: Jossey-Bass.

Sawyer, R.K. (2019). Individual and Group Creativity. In J.C. Kaufman, R.J. Sternberg (Eds.). The Cambridge Handbook of Creativity (pp. 567-586), second edition. New York: Cambridge University Press.

Starko, A.J. (2018). Creativity in the Classroom. Schools of Curious Delight, Sixth Edition, New York and London: Routledge.

Sternberg, R.J, \& Lubart, T.I. (1999). The Concept of Creativity: Prospects and Paradigms. In R.J. Sternberg (ed.), Handbook of Creativity (pp. 3-15). New York: Cambridge University Press.

Sternberg, R.J. (2017). Teaching for Creativity. In R.A. Beghetto, J.C. Kaufman (eds.), Nurturing Creativity in the Classroom, second edition (pp. 355-380). New York: Cambridge University Press.

Sternberg, R.J. (2019). Enhancing People's Creativity. In J.C. Kaufman \& R.J. Sternberg (eds.) The Cambridge Handbook of Creativity (pp. 88-103), second edition, New York: Cambridge University Press.

Szmidt, K.J. (2003d). Współczesne koncepcje wychowania do kreatywności i nauczania twórczości: przegląd stanowisk polskich. (Contemporary concepts of education for creativity and teaching creativity: a review of Polish positions). In: K.J. Szmidt (ed.), Dydaktyka twórczości. Koncepcje - problem - rozwiązania. (Didactics of creativity. Concepts - problems - solutions) (pp. 19-133). Kraków: Oficyna Wydawnicza „Impuls”. Szmidt, K.J. (2007). Pedagogika twórczości. (Pedagogy of creativity). Gdańsk: GWP Szmidt, K.J. (2013a). Pedagogika twórczości. (Pedagogy of creativity. Second revisited edition). Wydanie drugie poszerzone. Sopot: GWP.

Szmidt, K.J. (2013b). Trening kreatywności. Podręcznik dla pedagogów, psychologów i trenerów grupowych. Wyd. drugie poszerzone (Creativity training. Handbook for educators, 
psychologists, and group trainers. Second edition). Gliwice: Wydawnictwo HELION.

Szmidt, K.J. (2017). Edukacyjne uwarunkowania rozwoju kreatywności. (Educational conditions of creativity development). Łódź: Wyd. UŁ.

Szmidt, K.J. (2018a). Kreatywność - twórczość - postawa twórcza. Próba systematyzacji pojęć i teorii. (Creativeness - creativity - creative attitude. An attempt to systematize concepts and theories). In: B. Śliwerski, A, Rozmus (eds.). Alternatywy w edukacji (Alternatives in education). (pp. 127-154). Kraków: Oficyna Wydawnicza „Impuls”, WSIZ Rzeszów.

Szmidt, K.J. (2018b). Teoretyczno-badawcze nurty w polskiej kreatologii (Theoreticresearch trends in Polish creatology). „Nauki o Wychowaniu. Studia Interdyscyplinarne”. Kreatologia - nauka o twórczości i kreatywności jako przestrzeń interdyscyplinarna (Creatology - Science of Creativity and Creativeness as an Intedisciplinary Space). (s. 8-44), 7(2).

Szmidt, K.J. (2019). ABC kreatywności. Kontynuacje. (ABC of creativity. Continuations). Warszawa: Difin.

Szymczak, M. (1998). Słownik języka polskiego PWN, Tom I-III.

Treffinger, D.J., Schoonover, P.F., \& Selby, E.C. (2013). Educating for Creativity \& Innovation. Waco: Prufrock Press, Inc.

White, K. (2018). Unlocked: Assessment as the Key to Everyday Creativity in the Classroom. Bloomington: Solution Tree Press.

VanGundy, A.B. (2005). 101 Activities for Teaching Creativity and Problem Solving. San Francisco: Pfeiffer.

Corresponding author at: Krzysztof J. Szmidt, University of Lodz, Poland. E-mail: krzysztof.szmidt@uni.lodz.pl 